\title{
Status of Micronutrients in Soils of Jalgaon District, Maharashtra, India
}

\author{
S.S. Hadole ${ }^{1}$, P.A. Sarap ${ }^{1 *}$, S.R. Lakhe ${ }^{1}$, D.T. Dhule ${ }^{2}$ and J.N. Parmar ${ }^{3}$ \\ ${ }^{1}$ Department of Soil Science and Agricultural Chemistry, Dr. Panjabrao Deshmukh Krishi \\ Vidyapeeth, Akola-444104, (M.S.), India \\ ${ }^{2}$ College of Agriculture, Dr. PDKV, Akola - 444104,(M.S.) India. \\ ${ }^{3}$ AICRP on MAP\&B, NMPG, Dr.PDKV, Akola - 444104,(M.S.) India \\ *Corresponding author
}

\begin{abstract}
Keywords
Micronutrients

status, GPS,

Nutrient index

value

Article Info

Accepted:

12 June 2019

Available Online:

10 July 2019 Vidyapeeth, Akola, Maharashtra to assess the chemical properties, available sulphur and micronutrients status in soils of Jalgaon district in the year 2017-18. GPS based 480 soil samples $(0-20 \mathrm{~cm})$ from 15 tehsils in Jalgaon district of Maharashtra at $5 \mathrm{~km}$ grid were collected and analysed in the laboratory. The $\mathrm{pH}, \mathrm{EC}, \mathrm{OC}$ and $\mathrm{CaCO}_{3}$ of soils collected from the study area varied from 6.97 to $8.87,0.10$ to $0.69 \mathrm{dS} \mathrm{m}^{-1}, 1.19$ to $9.95 \mathrm{~g} \mathrm{~kg}^{-1}$ and 2.25 to 14.88 percent, respectively. Results further indicated that the $12.08,77.92,55.21,1.04$ and 5.65 per cent soil samples were found to be deficient in $\mathrm{S}, \mathrm{Zn} \mathrm{Fe}, \mathrm{Mn}$ and B, respectively. None of the soil samples were found low in $\mathrm{Cu}$. The nutrient index values are low for zinc (1.59) and boron (1.48), medium for iron (1.73) and high for sulphur (2.58), manganese (2.65), copper (2.96) and boron (2.37). The results obtained in the present study clearly showed a large variability in chemical properties of soil across the Jalgaon district. This information could aid in decision making for application of plant nutrients for higher monetary returns to the farmers and extension functionaries.
\end{abstract}

\section{A B S T R A C T}

An investigation was carried out at All India Co-ordinated Research Project on Micro and Secondary Nutrients and Pollutant Elements in Soils and Plants under Department of Soil Science \& Agricultural Chemistry, Dr. Panjabrao Deshmukh Krishi

\section{Introduction}

Increasing population pressure and overexploitation of productive lands creates serious problem of lowering the fertility status of soil and it leads to deterioration of soil. The deficiency of nutrients directly effects on the growth of crops and crop response become poor (Jagtap el al., 2018). Hence, for sustainability of the present agricultural system and for management of our soil resources, database regarding the fertility status of soils is required. Application of fertilizers by the farmers in fields without prior knowledge of soil fertility status might result in adverse effects on soils as well as crops both in terms of micronutrient deficiency and toxicity either by inadequate or overuse of fertilizers. With the invent of modern technologies of remote sensing, GIS and GPS, it is now possible to monitor the soil fertility and crop health through systematic 
surveys. This will be helpful to monitor the changes in fertility status of the studied area site specific nutrient requirement of the crop. It is anticipated that with higher yields and more intensive agriculture the secondary and micronutrient deficiency will increase both in amount and extent (NAAS, 2018). Imbalanced and inadequate use of fertilizers coupled with low use efficiency of other inputs led to decline in the response efficiency of chemical fertilizer nutrients under intensive agriculture in recent years. Micronutrients are important for maintaining soil health and increasing use efficiency of major nutrients and ultimately the crop productivity. The deficiency of micronutrients has become major constraint in sustainable crop productivity of soils and hence there is need to know the status of nutrients of the soil (Katkar et al., 2018). Keeping this in view, present study was undertaken in Jalgaon district of Maharashtra to study micro and secondary nutrient status of the soils and to identify areas of nutrient deficiencies.

\section{Materials and Methods}

\section{Description of the study area}

Jalgaon district of Maharashtra is situated between $20^{\circ}$ to $21^{\circ}$ North latitude and $74^{\circ} 55^{\prime}$ to $76^{\circ} 28^{\prime}$ East longitude. The district is divided into fifteen tehsils (Bodwad, Jamner, Jalgaon, Yaval, Rawer, Bhusawal, Muktainagar, Chopda, Amalner, Dharangaon, Erandol, Parola, Bhadgaon, Chalisgaon, Pachora). $5 \mathrm{~km}$ Grid sampling was done from all the fifteen tehsils.

\section{Soil sampling and analysis}

GPS based four hundred eighty surface soil samples $(0-20 \mathrm{~cm})$ were collected from all the tehsils of the district during the year 2017-18. The sampling villages were selected using stratified random method. The soil samples were processed and analyzed for $\mathrm{pH}$ and $\mathrm{EC}$ in soil: water suspensions $(1: 2.5 \mathrm{w} / \mathrm{v})$ as described by Jackson (1973). Organic carbon was determined by Wet oxidation method described by Walkley and Black (Nelson and Sommers, 1982) and free $\mathrm{CaCO}_{3}$ was determined by Rapid titration method (Piper, 1966). Available $S$ was estimated by turbidimetric method (Chesnin and Yien, 1951). Soil samples were extracted with 0.005 $\mathrm{M}$ diethylene triamine penta acetic acid (DTPA) for estimation of available $\mathrm{Zn}, \mathrm{Fe}, \mathrm{Cu}$ and $\mathrm{Mn}$ using Atomic Absorption Spectrophotometer (Lindsay and Norvell, 1978). Available boron was determined by $0.01 \mathrm{M} \mathrm{CaCl} 2$ extract with Azo-methine method (Berger and Troug, 1939). The nutrient indices were calculated by using the formula given by Parker et al., (1951) and categorized into low $(<1.66)$, medium $(1.66-$ 2.33) and high (> 2.33).

The soil categorization as low, medium and high followed in Maharashtra state in case of nutrients is depicted in Table 1.

\section{Results and Discussion}

\section{Soil Properties}

Data regarding chemical properties of soils in study area is depicted in Table 2. Investigated soils are neutral to slightly alkaline in reaction with $\mathrm{pH}$ varied from $6.97-8.87$ across the district. Neutral to alkaline $\mathrm{pH}$ may be attributed to the reaction of applied fertilizer material with soil colloids, which resulted in the retention of basic cations on the exchangeable complex of the soil. The electrical conductivity (EC) gives an indication about salt concentration of the soil and it varied from 0.1 to $0.69 \mathrm{dS} \mathrm{m}^{-1}$ with an average value of $0.25 \mathrm{dS} \mathrm{m}$. All the soils were non-saline in nature and suitable for healthy plant growth. The organic carbon content in soils ranged from 1.19 to $9.95 \mathrm{~g}$ 
$\mathrm{kg}^{-1}$. Calcium carbonate content in soils of the district varied from 2.25 to 14.88 per cent, High calcium carbonate is harmful; it reduces the concentration of micronutrient cations in soils to such a level that the sensitive plant suffers from deficiency of micronutrients (Deb et al., 2012).

\section{Sulphur status}

The available sulphur varied from very low to very high (2.19 to $46.59 \mathrm{~g} \mathrm{~kg}^{-1}$ ) with 12.08 per cent deficiency as presented in Table 3 and 4. The intensive cultivation of crops and application of fertilizers devoid of sulphur might be depleting the sulphur from soil. The application of balanced nutrition to the crops under intensive cultivation is essential for maintaining the soil fertility and sustainable productivity.

\section{Micronutrients status}

Data pertaining to micronutrient status and percent sample deficient of the study area is depicted in Table 3 and 4, respectively. DTPA-Zn of Jalgaon district as a whole, varied from 0.10 to $3.48 \mathrm{mg} \mathrm{kg}^{-1}$ indicating 77.92 per cent deficiency. The highest deficiency of zinc (100\%) was observed in
Erandol and Pachora tehsil followed by Amalner (97.06\%). The availability of micronutrient cations is generally low in alkaline soils and crops grown on these soils suffer from hidden hunger (Malewar, 2005). Under alkaline soil condition $(\mathrm{pH}$ higher then 7.0) the micronutrient cations are changed largely to their oxides and hydroxides which ultimately reduced their availability (Deb et al., 2012). DTPA-Fe content showed wide variation (1.19 to $39.10 \mathrm{mg} \mathrm{kg}^{-1}$ ) in the soils of the study area. Considering $4.5 \mathrm{mg} \mathrm{kg}^{-1}$ as critical limit of available iron, the distribution of soil samples under deficient category was $55.21 \%$, indicating that the soils are becoming deficient in iron followed by zinc. Increased removal of micronutrients as a consequence of adoption of high yielding varieties and intensive cropping together with a shift towards the use of high analysis NPK fertilizers which might have caused decline in the level of micronutrients in the soil below the critical level which are required for normal productivity of crops (Zende, 1987). The DTPA extractable $\mathrm{Cu}$ in the soils ranged from 0.21 to $5.67 \mathrm{mg} \mathrm{kg}^{-1}$. All the soils in Jalgaon district were found sufficient in $\mathrm{Cu}$ content. The DTPA-Mn status of soils ranged from 0.63 to $53.34 \mathrm{mg} \mathrm{kg}^{-1}$ with only $1.04 \%$ deficiency.

Table.1 Categorization of soil parameters and nutrients

\begin{tabular}{|c|c|c|c|c|}
\hline Sr. No. & Parameters & Low & Medium & High \\
\hline 1 & $\mathrm{pH}(1: 2.5)$ & $<6.5$ (Acidic) & 6.5-7.5 (Neutral) & >7.5 (Alkaline) \\
\hline 2 & $\mathrm{EC}\left(\mathrm{dS} \mathrm{m} \mathrm{m}^{-1}\right)$ & $<1.0$ & $1-2$ & $>2.0$ \\
\hline 3 & O.C. $\left(\mathrm{g} \mathrm{kg}^{-1}\right)$ & $<4.0$ & $4-8$ & $>8.0$ \\
\hline 4 & $\mathrm{CaCO}_{3}(\%)$ & $<3.0$ & $3-8$ & $>8.0$ \\
\hline 5 & $\mathrm{~S}\left(\mathrm{mg} \mathrm{kg}^{-1}\right)$ & $<10.0$ & $10-20$ & $>20.0$ \\
\hline 6 & $\mathrm{Zn}\left(\mathrm{mg} \mathrm{kg}{ }^{-1}\right)$ & $<0.60$ & $0.6-1.80$ & $>1.80$ \\
\hline 7 & $\mathrm{Fe}\left(\mathrm{mg} \mathrm{kg}^{-1}\right)$ & $<4.50$ & $4.50-18.0$ & $>18.0$ \\
\hline 8 & $\mathrm{Cu}\left(\mathrm{mg} \mathrm{kg}^{-1}\right)$ & $<0.20$ & $0.20-0.80$ & $>0.80$ \\
\hline 9 & $\operatorname{Mn}\left(\mathrm{mg} \mathrm{kg}^{-1}\right)$ & $<2.0$ & $2.0-8.0$ & $>8.0$ \\
\hline 10 & $\mathrm{~B}\left(\mathrm{mg} \mathrm{kg}^{-1}\right)$ & $<0.50$ & $0.50-1.0$ & $>1.0$ \\
\hline 11 & Mo $\left(\mathrm{mg} \mathrm{kg}^{-1}\right)$ & $<0.10$ & $0.10-0.40$ & $>0.40$ \\
\hline
\end{tabular}


Table.2 Chemical properties of soils in different tehsils of Jalgaon District

\begin{tabular}{|c|c|c|c|c|c|c|c|c|c|c|}
\hline \multirow[t]{2}{*}{$\begin{array}{l}\text { S. } \\
\text { N. }\end{array}$} & \multirow[t]{2}{*}{$\begin{array}{l}\text { Name of } \\
\text { Tehsil }\end{array}$} & \multirow[t]{2}{*}{$\begin{array}{l}\text { Total No. } \\
\text { of samples }\end{array}$} & \multicolumn{2}{|c|}{ pH (1:2.5) } & \multicolumn{2}{|c|}{$\mathrm{EC}\left(\mathrm{dS} \mathrm{\textrm {m } ^ { - 1 } )}\right.$} & \multicolumn{2}{|c|}{$\mathrm{CaCO}_{3}(\%)$} & \multicolumn{2}{|c|}{$\begin{array}{l}\text { Organic carbon } \\
\qquad\left(\mathrm{g} \mathrm{kg}^{-1}\right)\end{array}$} \\
\hline & & & Range & Mean & Range & Mean & Range & Mean & Range & Mean \\
\hline 1 & Bodwad & 26 & $7.20-8.01$ & 7.61 & $0.10-0.51$ & 0.30 & $6.25-11.13$ & 9.27 & $2.38-4.60$ & 3.59 \\
\hline 2 & Jamner & 48 & $7.14-8.25$ & 7.74 & $0.11-0.69$ & 0.29 & $7.00-14.75$ & 10.21 & $1.19-6.89$ & 3.17 \\
\hline 3 & Jalgaon & 32 & $7.44-8.31$ & 8.02 & $0.13-0.49$ & 0.29 & $10.75-14.88$ & 13.42 & $1.63-8.47$ & 4.66 \\
\hline 4 & Yaval & 35 & 7.41-8.39 & 8.04 & $0.15-0.67$ & 0.28 & $2.25-11.63$ & 8.23 & $1.34-6.09$ & 4.34 \\
\hline 5 & Rawer & 30 & 7.94-8.59 & 8.24 & $0.15-0.42$ & 0.26 & $6.13-12.38$ & 8.52 & $3.27-7.87$ & 5.9 \\
\hline 6 & Bhusawal & 20 & 7.97-8.29 & 8.11 & $0.25-0.46$ & 0.34 & $7.25-10.00$ & 8.5 & $4.60-9.36$ & 6.71 \\
\hline 7 & Muktainagar & 28 & $7.41-8.24$ & 7.87 & $0.18-0.34$ & 0.24 & $4.88-9.75$ & 6.55 & $4.16-6.24$ & 5.22 \\
\hline 8 & Chopda & 38 & $7.42-8.40$ & 7.82 & $0.19-0.57$ & 0.34 & $4.88-13.75$ & 9.13 & $4.60-6.53$ & 5.76 \\
\hline 9 & Amalner & 34 & $6.97-8.19$ & 7.62 & $0.10-0.27$ & 0.16 & $4.25-10.13$ & 6.78 & $3.71-9.95$ & 7.22 \\
\hline 10 & Dharangaon & 25 & $7.89-8.26$ & 8.06 & $0.12-0.30$ & 0.21 & $4.63-9.75$ & 7.29 & $4.31-7.57$ & 6.13 \\
\hline 11 & Erandol & 24 & $7.33-8.87$ & 7.87 & $0.13-0.67$ & 0.36 & $4.75-14.88$ & 10.25 & $4.75-7.28$ & 6.06 \\
\hline 12 & Parola & 35 & $7.56-8.33$ & 7.89 & $0.10-0.38$ & 0.21 & $2.50-9.75$ & 6.31 & $3.56-6.39$ & 4.83 \\
\hline 13 & Bhadgaon & 26 & $7.25-8.21$ & 7.95 & $0.10-0.46$ & 0.21 & $3.75-9.63$ & 6.68 & $4.60-7.43$ & 6.15 \\
\hline 14 & Chalisgaon & 46 & $7.47-8.31$ & 7.99 & $0.10-0.35$ & 0.18 & $3.75-13.50$ & 7.65 & $4.31-7.87$ & 5.78 \\
\hline 15 & Pachora & 33 & $7.78-8.21$ & 8.00 & $0.13-0.28$ & 0.19 & $3.63-13.75$ & 8.44 & $5.94-9.50$ & 7.17 \\
\hline \multicolumn{2}{|c|}{ District average } & 480 & 6.97-8.87 & 7.91 & 0.10-0.69 & 0.25 & $2.25-14.88$ & 8.52 & 1.19-9.95 & 5.40 \\
\hline
\end{tabular}


Table.3 Available sulphur and micronutrient status $\left(\mathrm{mg} \mathrm{kg}^{-1}\right)$ in soils of different tehsils in Jalgaon District

\begin{tabular}{|c|c|c|c|c|c|c|c|c|c|c|c|c|c|}
\hline \multirow{2}{*}{$\begin{array}{l}\text { S. } \\
\text { N. }\end{array}$} & \multirow{2}{*}{$\begin{array}{l}\text { Name of } \\
\text { Tehsil }\end{array}$} & \multicolumn{2}{|l|}{$\mathbf{S}$} & \multicolumn{2}{|c|}{ DTPA-Zn } & \multicolumn{2}{|c|}{ DTPA-Fe } & \multicolumn{2}{|c|}{ DTPA-Cu } & \multicolumn{2}{|c|}{ DTPA-Mn } & \multicolumn{2}{|l|}{ B } \\
\hline & & Range & Mean & Range & Mean & Range & Mean & Range & Mean & Range & Mean & Range & Mean \\
\hline 1 & Bodvad & $11.89-40.56$ & 33.78 & $0.11-2.26$ & 1.04 & $1.23-7.82$ & 2.27 & $0.31-2.66$ & 1.45 & $4.77-32.58$ & 14.50 & $0.27-1.22$ & 0.89 \\
\hline 2 & Jamner & $5.10-45.37$ & 28.60 & $0.12-2.97$ & 1.62 & $1.47-39.10$ & 8.84 & $0.49-5.67$ & 2.55 & $2.36-38.74$ & 18.85 & $0.10-1.18$ & 0.56 \\
\hline 3 & Jalgaon & $4.50-44.74$ & 26.86 & $0.19-3.11$ & 1.38 & $2.19-19.67$ & 8.92 & $0.21-4.80$ & 2.19 & $5.73-53.34$ & 31.63 & $0.24-0.65$ & 0.46 \\
\hline 4 & Yawal & $10.55-43.65$ & 29.21 & $0.10-3.27$ & 1.24 & $1.54-5.47$ & 2.61 & $0.36-5.11$ & 2.06 & $2.09-45.46$ & 24.21 & $0.36-1.09$ & 0.75 \\
\hline 5 & Raver & $12.99-45.61$ & 28.59 & $0.10-1.83$ & 0.83 & $1.68-3.82$ & 2.44 & $0.27-5.26$ & 1.44 & $0.63-32.74$ & 10.12 & $0.10-1.05$ & 0.46 \\
\hline 6 & Bhusaval & $6.84-42.37$ & 26.38 & $0.13-2.07$ & 0.45 & $1.36-4.27$ & 1.98 & $0.22-4.35$ & 1.42 & $1.30-30.90$ & 10.02 & $0.10-0.95$ & 0.43 \\
\hline 7 & Muktainagar & $3.29-46.28$ & 25.14 & $0.10-2.11$ & 0.62 & $1.21-3.94$ & 2.01 & $0.21-5.31$ & 1.94 & $2.05-48.14$ & 18.45 & $0.26-0.61$ & 0.47 \\
\hline 8 & Chopda & $2.19-43.50$ & 25.64 & $0.11-3.50$ & 0.96 & $1.38-4.43$ & 2.70 & $0.58-5.02$ & 2.43 & $2.05-47.12$ & 23.45 & $0.20-0.58$ & 0.40 \\
\hline 9 & Amalner & $5.01-46.59$ & 20.36 & $0.10-1.58$ & 0.34 & $1.57-19.46$ & 5.84 & $0.41-3.91$ & 1.81 & $3.03-32.32$ & 12.10 & $0.13-1.18$ & 0.40 \\
\hline 10 & Dhadgaon & $3.00-42.94$ & 25.75 & $0.14-1.97$ & 0.47 & $3.02-21.24$ & 8.19 & $0.69-3.83$ & 1.92 & $4.11-33.18$ & 14.32 & $0.18-0.60$ & 0.39 \\
\hline 11 & Erandol & $7.87-45.00$ & 27.71 & $0.12-1.22$ & 0.35 & $1.19-12.69$ & 3.26 & $0.72-4.80$ & 1.86 & $3.73-29.22$ & 14.74 & $0.47-0.77$ & 0.61 \\
\hline 12 & Parola & $4.63-43.56$ & 19.59 & $0.10-1.78$ & 0.52 & $1.57-15.94$ & 8.10 & $0.42-3.08$ & 1.70 & $3.05-29.70$ & 14.19 & $0.29-0.87$ & 0.63 \\
\hline 13 & Bhadgaon & $8.02-41.89$ & 24.94 & $0.13-2.20$ & 0.51 & $1.40-19.53$ & 7.80 & $0.31-2.09$ & 0.94 & $3.93-23.04$ & 12.51 & $0.15-0.98$ & 0.41 \\
\hline 14 & Chalisgaon & $6.48-46.25$ & 23.88 & $0.10-2.62$ & 0.59 & $2.70-28.70$ & 10.76 & $0.52-2.34$ & 1.23 & $4.31-40.40$ & 22.18 & $0.14-1.04$ & 0.57 \\
\hline 15 & Pachora & $8.18-45.91$ & 33.83 & $0.24-1.20$ & 0.65 & $2.48-37.50$ & 11.16 & $0.97-4.72$ & 2.20 & $5.86-35.18$ & 18.15 & $0.29-0.81$ & 0.45 \\
\hline \multicolumn{2}{|c|}{ District average } & $2.19-46.59$ & 26.56 & $0.10-3.48$ & 0.82 & 1.19-39.10 & 6.17 & $0.21-5.67$ & 1.85 & 0.6353 .34 & 17.95 & $0.10-1.22$ & 0.53 \\
\hline
\end{tabular}


Table.4 Percent samples deficient for available sulphur and micronutrients in soils of different tehsils in Jalgaon District

\begin{tabular}{|c|c|c|c|c|c|c|c|}
\hline \multirow[t]{2}{*}{ S. No. } & \multirow{2}{*}{$\begin{array}{l}\text { Name of } \\
\text { Tehsil }\end{array}$} & \multicolumn{6}{|c|}{ Percent of samples deficit for available sulphur and micronutrients } \\
\hline & & Sulphur & DTPA-Zn & DTPA-Fe & DTPA-Mn & DTPA-Cu & Boron \\
\hline $\mathbf{1}$ & Bodvad & 00 & 65.39 & 92.31 & 00 & 00 & 19.23 \\
\hline 2 & Jamner & 16.67 & 31.25 & 47.92 & 00 & 00 & 45.83 \\
\hline 3 & Jalgaon & 3.13 & 53.13 & 21.88 & 00 & 00 & 75.0 \\
\hline 4 & Yawal & 00 & 54.28 & 82.86 & 00 & 00 & 28.57 \\
\hline 5 & Raver & 00 & 73.33 & 100.0 & 13.33 & 00 & 70.0 \\
\hline 6 & Bhusaval & 15.0 & 95.00 & 100.0 & 5.00 & 00 & 45.0 \\
\hline 7 & Muktainagar & 28.57 & 89.29 & 100.0 & 00 & 00 & 71.43 \\
\hline 8 & Chopda & 28.95 & 76.32 & 100.0 & 00 & 00 & 92.11 \\
\hline 9 & Amalner & 23.53 & 97.06 & 47.06 & 00 & 00 & 73.53 \\
\hline 10 & Dhadgaon & 16.0 & 96.00 & 20.00 & 00 & 00 & 88.0 \\
\hline 11 & Erandol & 8.33 & 100.00 & 79.17 & 00 & 00 & 8.33 \\
\hline 12 & Parola & 20.0 & 93.99 & 25.71 & 00 & 00 & 22.86 \\
\hline 13 & Bhadgaon & 7.69 & 96.15 & 30.77 & 00 & 00 & 84.62 \\
\hline 14 & Chalisgaon & 4.35 & 84.78 & 13.04 & 00 & 00 & 39.13 \\
\hline 15 & Pachora & 6.06 & 100.00 & 9.09 & 00 & 00 & 84.85 \\
\hline & District average & 12.08 & 77.92 & 55.21 & 1.04 & 00 & 56.45 \\
\hline
\end{tabular}


Table.5 Percent sample deficit and nutrient indices of soils in different tehsils of Jalgaon district

\begin{tabular}{|c|c|c|c|c|}
\hline \multirow{2}{*}{ Nutrients } & \multicolumn{3}{|c|}{ Percent samples } & Nutrient \\
\cline { 2 - 4 } & Low & Medium & High & index \\
\hline $\mathrm{S}$ & 12.08 & 22.92 & 65.0 & 2.53 \\
\hline $\mathrm{Zn}$ & 77.92 & 8.96 & 13.12 & 1.59 \\
\hline $\mathrm{Fe}$ & 55.21 & 39.79 & 5.00 & 1.50 \\
\hline $\mathrm{Cu}$ & 1.04 & 21.25 & 77.71 & 2.77 \\
\hline $\mathrm{Mn}$ & 00 & 12.92 & 87.08 & 2.87 \\
\hline $\mathrm{B}$ & 56.45 & 39.38 & 4.17 & 1.48 \\
\hline
\end{tabular}

Available boron in soils of all the tehsils ranged from 0.10 to $1.22 \mathrm{mg} \mathrm{kg}^{-1}$ with a mean value of $0.53 \mathrm{mg} \mathrm{kg}^{-1}$. The range of available boron in soils of different states of India varied from traces to $12.2 \mathrm{mg} \mathrm{kg}^{-1}$ (Das, 2007). Boron deficiency was observed in 55.45 per cent samples. The highest boron deficiency was noticed in Chopda tehsil.

\section{Nutrient indices}

Considering the concept of 'Soil Nutrient Index' the soils of the study area (Table 5) were found in the category of 'low fertility status' for zinc (1.59), iron (1.50) and boron (1.48), and 'high' for sulphur (2.53), manganese (2.87) and copper (2.77) considering whole district as one unit. In nutshell, overall fertility rating for micronutrients in the soils of Jalgaon district revealed low in $\mathrm{Zn}, \mathrm{Fe}$ and Bo and high in $\mathrm{S}$, $\mathrm{Mn}$ and $\mathrm{Cu}$ status. The areas where the status of nutrients are high, may show deficiency in near future if the due care will not be taken for addition of organic manures and inorganic micronutrient fertilizers based on soil testing by the cultivators in the districts for intensive cultivation of different crops (Malewar, 2005).

The present study revealed that there is wide variation in micronutrient status of soils of Jalgaon district in Maharashtra. The soils are low in available zinc, iron and boron and high in available sulphur, manganese, copper.
Deficient nutrients have to be restored through chemical fertilizers and / or organic manures to maintain soil health. The current status of available sulphur and micronutrients in soils of Jalgaon district will be helpful to suggest the efficient ways and methods of balanced nutrient application for enhancing the yields by using recommended quantities of organic manures and inorganic fertilizers in the areas of major and micro-nutrients deficiency.

\section{Acknowledgements}

The author's are highly grateful to the Project Coordinator, AICRP on Micro and Secondary Nutrients and Pollutant Elements in Soils and Plants, IISS, Bhopal and Head, Department of Soil Science and Agricultural Chemistry, Dr. PDKV., Akola for providing necessary facilities and funds to carry out this work.

\section{References}

Berger, K.C. and Truog, E. 1939. Boron determination in soils and plants. Industrial and Engineering Chemistry Analytical Edition 11, 540-544.

Chesnin, L and Yein, C. H. 1951. Turbidimetric determination of available sulphates. Soil Science Society of America Proceedings 15, 149-157.

Das K. K., 2007. Boron: In Micronutrients: Their Behavious in Soils and Plants. Kalyani Publishers, Ludhiana. Pp 151- 
189

Deb, D. L., Sakal, L. R. and Datta, S. P. 2012. Micronutrients: In: Fundamental of Soil Science. Indian Society of Soil Science: 461-490.

Jackson, M. L. 1973. Soil Chemical Analysis (Eds.) Prentice Hall of India, Pvt. Ltd New Delhi.

Jagtap Mayuri, Chaudhari Ramesh, Thakare Ritu and Patil Tulshidas. 2018. Mapping of soil micronutrient status based on GPS-GIS and biological properties of Ajang village of Dhule tehsil of Dhule district Maharashtra. Journal of Pharmacognosy and Phytochemistry 7 (5), 3270-3275

Katkar, R.N., Lakhe, S.R., Kharche, V.K., Magare, P.N. and Laharia, G.S. (2018) Spatial variability of major and micro nutrients in soils of Bhandara District, Maharashtra. Agropedology 27 (01), 5662.

Lindsay, W. L., and Norvell, W. A. 1978. Development of a DTPA soil test for zinc, iron, manganese and copper. Soil Science Society of America Journal 42, 421-428.

Malewar, G. U., 2005. Micronutrient stresses in soils and crops: Serious sickness and clinical approaches for sustainable agriculture. Journal of Indian Society of Soil Science 53 (4), 484-499

NAAS. 2018. Soil Health: New Policy Initiative for Farmer's Welfare. Policy Brief No. 3, National Academy of Agricultural Sciences, New Delhi. $4 p$

Nelson, D. W. and Sommers, L. E. 1982. In: Methods of Soil Analysis, Part II, Chemical and Microbiological Methods by Page, A. L., R. H. Miller and D. R. Keeney (eds.) Agronomy Monograph No. 9 ( $2^{\text {nd }}$ edition) American Society of Agronomy and Soil Science Society of America, Madison, Wisconsin, USA : 570-572.

Parker, F. W., Nelson, W. L, Winters E. and Miles, I. F. 1951. The broad interpretation and application of soil test information. Agronomy Journal 43, 105-112.

Piper, C. S. (1966). Soil and Plant Analysis, Hans. Pub. Bombay. Asian Ed. 368374.

Zende, G. K. 1987. Invited paper in proceedings on micronutrient stress in crop plants, MPKV, Rahuri.

\section{How to cite this article:}

Hadole, S.S., P.A. Sarap, S.R. Lakhe, D.T. Dhule and Parmar, J.N. 2019. Status of Micronutrients in Soils of Jalgaon District, Maharashtra, India. Int.J.Curr.Microbiol.App.Sci. 8(07): 1432-1439. doi: https://doi.org/10.20546/ijcmas.2019.807.171 